\title{
Effects of chalcone derivatives on players of the immune system
}

\author{
This article was published in the following Dove Press journal: \\ Drug Design, Development and Therapy \\ 19 August 2015 \\ Number of times this article has been viewed
}

\author{
Jian Sian Lee \\ Syed Nasir Abbas Bukhari \\ Norsyahida Mohd Fauzi \\ Drug and Herbal Research Center, \\ Faculty of Pharmacy, Universiti \\ Kebangsaan Malaysia, Kuala Lumpur, \\ Malaysia
}

\begin{abstract}
The immune system is the defense mechanism in living organisms that protects against the invasion of foreign materials, microorganisms, and pathogens. It involves multiple organs and tissues in human body, such as lymph nodes, spleen, and mucosa-associated lymphoid tissues. However, the execution of immune activities depends on a number of specific cell types, such as B cells, T cells, macrophages, and granulocytes, which provide various immune responses against pathogens. In addition to normal physiological functions, abnormal proliferation, migration, and differentiation of these cells (in response to various chemical stimuli produced by invading pathogens) have been associated with several pathological disorders. The unwanted conditions related to these cells have made them prominent targets in the development of new therapeutic interventions against various pathological implications, such as atherosclerosis and autoimmune diseases. Chalcone derivatives exhibit a broad spectrum of pharmacological activities, such as immunomodulation, as well as anti-inflammatory, anticancer, antiviral, and antimicrobial properties. Many studies have been conducted to determine their inhibitory or stimulatory activities in immune cells, and the findings are of significance to provide a new direction for subsequent research. This review highlights the effects of chalcone derivatives in different types of immune cells.
\end{abstract}

Keywords: macrophages, neutrophils, T-cells

\section{Introduction}

The immune system is the fundamental protective mechanism that functions in defending living organisms against infections. In human beings, numerous organs and tissues, such as the spleen, lymph nodes, tonsils, adenoids, and the thymus, constitute the main characters of the immune system. In order to establish an infection, pathogens must overcome the physical barriers, such as mucus and enzymes, to cause adverse effect in living cells. Pathogens that evade the surface barriers will be directed to the next level of defense mechanisms. In general, there are two different types of immune responses with regards to invading pathogens. Innate or nonspecific immunity displays the first line of host defense against pathogens, involving the phagocytes, such as macrophages and dendritic cells. Acquired or specific immunity involves the production of antigen-specific antibodies, which act by eliminating pathogens in the late phase of infection and which produce immunological memory. ${ }^{1}$

Abnormalities in proliferation or function of the immune cells have been associated with some pathological conditions, such as autoimmune diseases, tuberculosis, and atherosclerosis. ${ }^{2,3}$ Patients with severe tuberculosis were reported to exhibit depletion of $\mathrm{CD}^{+}$and $\mathrm{CD}^{+} \mathrm{T}$ lymphocytes, which can be a sign of suppressed immunity in these patients. It is suggested that macrophages infected by Mycobacterium tuberculosis may secrete a heat-labile factor that is cytotoxic to the T lymphocytes, causing
Correspondence: Norsyahida Mohd Fauzi Drug and Herbal Research Center, Faculty of Pharmacy, Universiti Kebangsaan Malaysia, Jalan Raja Muda Abdul Aziz, 50300 Kuala Lumpur, Malaysia

Tel +60392898053

Email drnorsyahida@ukm.edu.my 
weakened immune system in individuals suffering from tuberculosis. ${ }^{4}$ In atherosclerosis, circulating monocytes adhere to the injured endothelium and migrate into the tunica intima with the expression of cytokines and mediators. The monocytes are differentiated into macrophages in the intimal layer. Macrophages take up oxidized low-density lipoprotein via scavenger receptors, and form foam cells, which play a central role in atherogenesis. ${ }^{5}$ Immunomodulatory agents, such as interferon- $\beta$, glatiramer acetate and mitoxantrone, have been used to relieve multiple sclerosis. ${ }^{6}$ Intravenous immunoglobulin is also an option to treat several autoimmune diseases, such as systemic lupus erythematosus, multiple sclerosis, and myasthenia gravis. ${ }^{7}$

Chalcones (1,3-diaryl-2-propen-1-ones) are precursors for flavonoid and isoflavonoids, which can be found in many edible plants (Figure 1). Chalcone derivatives have been reported to have several pharmacological activities, such as antimalarial, antimicrobial, anticancer, antiHIV, and antinociceptive activities. Moreover, chalcone derivatives have been shown to possess anti-inflammatory properties. ${ }^{8-13}$ Two studies reported that chalcone derivatives inhibit secretory phospholipase $\mathrm{A}_{2}, \mathrm{COX}$, lipoxygenases, proinflammatory cytokines production, neutrophil chemotaxis, phagocytosis, and production of reactive oxygen species (ROS). ${ }^{14,15}$ The pharmacological effects and signaling pathways mediated by chalcone derivatives have been discussed extensively in previous reviews. ${ }^{16-18}$ However, the specific effects of chalcone derivatives in various types of immune cells have not been discussed. In this review, the action of these chalcone derivatives in several immune cells are discussed in detailed to provide new insights for further studies of these compounds, for the discovery of potential agents against pathological conditions associated with immune diseases.

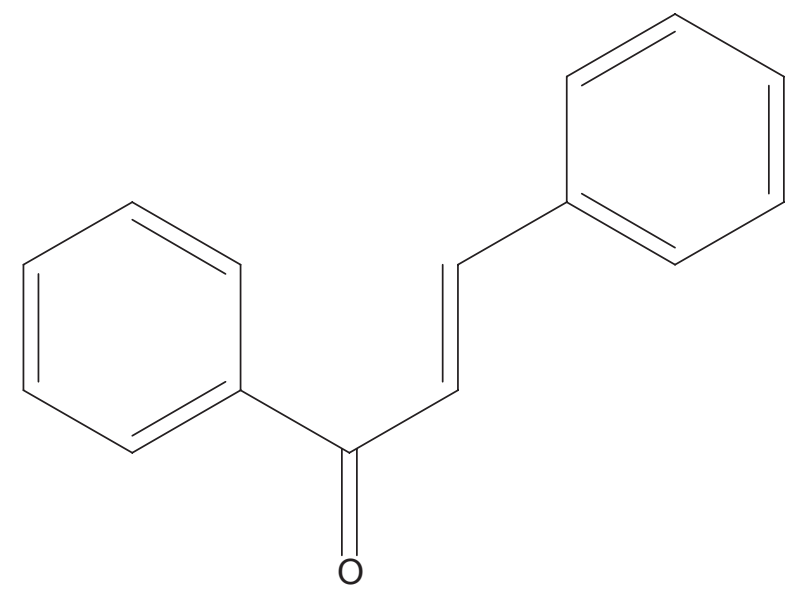

Figure I Chalcone backbone.

\section{Immune system and immunomodulators}

Innate and adaptive immunities work in complementarity with one another to provide an overall protection to the human body. Innate immunity employs an antigen-independent defense mechanism that will provide host defense immediately or within hours after exposure to the pathogens. It has no capacity for immunological memory. Therefore, this type of immunity will be unable to recognize the same pathogen encountered by the body in the future. In general, innate immunity consists of four types of defense: physical barriers (skin and mucous membrane), physiological barriers (temperature, low $\mathrm{pH}$, and chemical mediators), endocytosis/phagocytosis, and inflammation. Innate immunity comprises of phagocytic cells (neutrophils, monocytes, and macrophages), cells secreting inflammatory mediators (basophils, mast cells, and eosinophils), and natural killer (NK) cells. The process of phagocytosis involves a number of significant steps, including recognition and binding of cell surface receptors to the pathogen; actin polymerization under the membrane, stimulated by signals from the pathogen-receptor complex; and actin-rich membrane extension surrounding and attracting the pathogen towards the cell center. This is followed by the formation of a phagolysosome containing acidic and hydrolytic enzymes, which is responsible for destroying the ingested pathogen. ${ }^{19}$ Several molecular components, including complement, acute-phase proteins, and cytokines, are utilized to conduct innate immune activities. Innate immunity promotes the recruitment of immune cells to the sites of infection, which is regulated by soluble mediators known as cytokines. These mediators will enhance the secretion of antibodies as well as activate the complement system, facilitating phagocytosis process by opsonizing the targeted antigen. Acute-phase proteins, such as C-reactive protein, will increase resistance to infection and promote the repair of damaged tissue. Innate immunity can also stimulate adaptive immune response with the help of a group of specialized cells known as antigen-presenting cells (APCs).

Unlike innate immunity, the adaptive immune response involves antigen-specific antibodies, and a certain time interval is required for the maximal response to be achieved after exposure to the antigen. This immune response is the most essential defense when innate immunity is insufficient for removing pathogens from the body. Immunological memory capacity distinguishes adaptive immunity from innate immunity, whereby adaptive immunity can elicit a more rapid and effective immune response upon subsequent antigen encounter. ${ }^{20}$ Adaptive responses are mainly conducted by T cells, facilitated by APCs and B cells. Upon stimulation 
by pathogens, proliferation of antigen-specific $\mathrm{B}$ and $\mathrm{T}$ cells occurs in acquired immunity. APCs display the processed antigen to lymphocytes and collaborate with them to elicit the immune response. B cells secrete antigen-specific immunoglobulin or antibodies to eliminate invading microorganisms. ${ }^{21}$ $\mathrm{T}$ cells eradicate intracellular pathogens by activating macrophages and by killing virally infected cells.

Adaptive immune responses can be further divided into antibody-mediated immunity and cell-mediated immunity. In antibody-mediated immunity, antigen receptors located on $\mathrm{B}$ cells recognize and bind to the antigens, causing the $\mathrm{B}$ cells to proliferate and differentiate into antibody-secreting plasma cells under the stimulation of $\mathrm{T}$ helper (Th) cells. The generated antigen-specific antibodies will, in turn, bind to antigens on the surface of pathogens, directing them to be destroyed by various processes, such as neutralization, complement activation, and phagocytosis. ${ }^{22}$ Activation of cell-mediated immunity requires the interaction of T-cells with APCs displaying antigen fragments on major histocompatibility complex (MHC) I molecules. Cell-mediated immunity destroys intracellular pathogens by activating antigen-specific cytotoxic $\mathrm{T}$ cells, macrophages, and NK cells as well as by stimulating the secretion of cytokines for further immune responses.

Immunomodulation is the application of a drug or compound in order to manipulate an immune response to achieve an expected outcome. Immunomodulators are substances that have been found to manipulate the immune system response to a threat upon it. They modify and potentiate the capability of the immune system to a well-prepared state for any unpleasant threat coming to it. The immune system in a highly prepared state can provide powerful and effective protection against any intruding organisms. Over the past decades, proteins, lipids, and natural compounds, such as IFN- $\gamma$, steroids, and phenolics have been shown to possess immunomodulatory properties. ${ }^{23-26}$ Clinically, immunomodulators can be categorized as immunoadjuvants, immunostimulants, and immunosuppressants. ${ }^{27}$ Immunoadjuvants can improve the efficacy of vaccines, while immunostimulants are nonspecific agents that may increase the resistance of body against infection. Immunosuppressants are a group of drugs that are usually administered in the form of combination regimens to suppress immune responses in individuals suffering from organ transplant rejection and autoimmune diseases. ${ }^{28,29}$

\section{Chalcones as immunomodulatory agents}

Chalcones (1,3-diaryl-2-propen-1-ones) are $\alpha, \beta$-unsaturated ketones, comprised of two aromatic rings, that function as precursors in the synthesis of flavonoids and isoflavonoids. There are several forms of chalcones present in edible fruits, such as phloretin derivatives, arbutin, phloretin glucoside, and chalconaringenin. ${ }^{30}$ Chalcone derivatives can be synthesized in the laboratory by various methods involving multiple types of catalysts that have been used by researchers. Recently, we reviewed the different methods and catalysts used for chalcone synthesis, among which the Claisen-Schmidt condensation reaction, between a ketone and aldehyde in the presence of polar solvent, is the most common method. ${ }^{31}$ Many pharmacological activities have been reported on chalcone derivatives with different substituents, as mentioned earlier. A study conducted by Yadav et al revealed that chalcone derivatives with methoxy groups at position 2 and 4 of benzaldehyde exerted the most optimal antimalarial effect. ${ }^{32} 4^{\prime}$-methoxy-substituted dihydrochalcones were reported, possessing inhibition activity against Plasmodium falciparum. ${ }^{33}$ Chalcone derivatives with rhodanine3 -acetic acid moieties were also found to inhibit the growth of clinical isolates of multidrug-resistant gram-positive bacteria. ${ }^{34}$ In addition, there is evidence indicating that chalcone derivatives demonstrated preferential inhibition against the growth of human cancer cell lines MDA-MB-231 (estrogen receptornegative) and MCF7 (estrogen receptor-positive) over normal breast epithelial cell lines, at low concentrations. ${ }^{35}$ Meanwhile, parasiticin C (1) (5,7-dihydroxy-6-methyl-4-phenyl-8-(3phenyltrans-acryloyl)-3,4-dihydro-1-benzopyran-2-one), a chalcone isolated from the leaves of Cyclosorus parasiticus was documented to exert antiproliferative activity against human cancer cell lines in vitro, especially toward the HepG2 hepatocellular carcinoma cell line. ${ }^{36}$ In this review, the effects of chalcone and its derivatives in several immune cell types have been discussed in the following sections (Table 1).

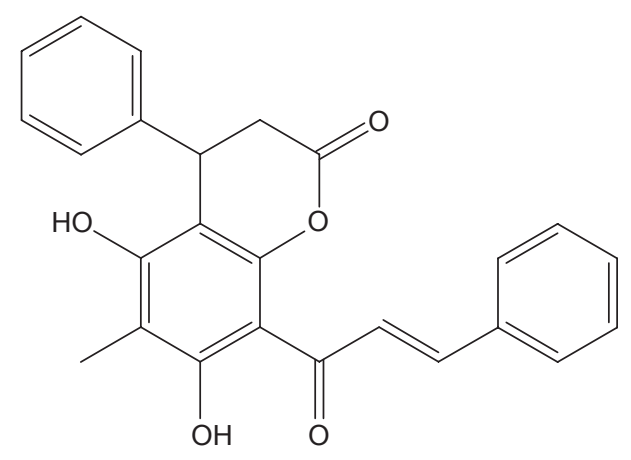

(1)

\section{Dendritic cells}

Dendritic cells are antigen-presenting cells that are more efficient in displaying antigen to $\mathrm{T}$ cells compared with macrophages. These cells can be found in the lymphoid organs, 


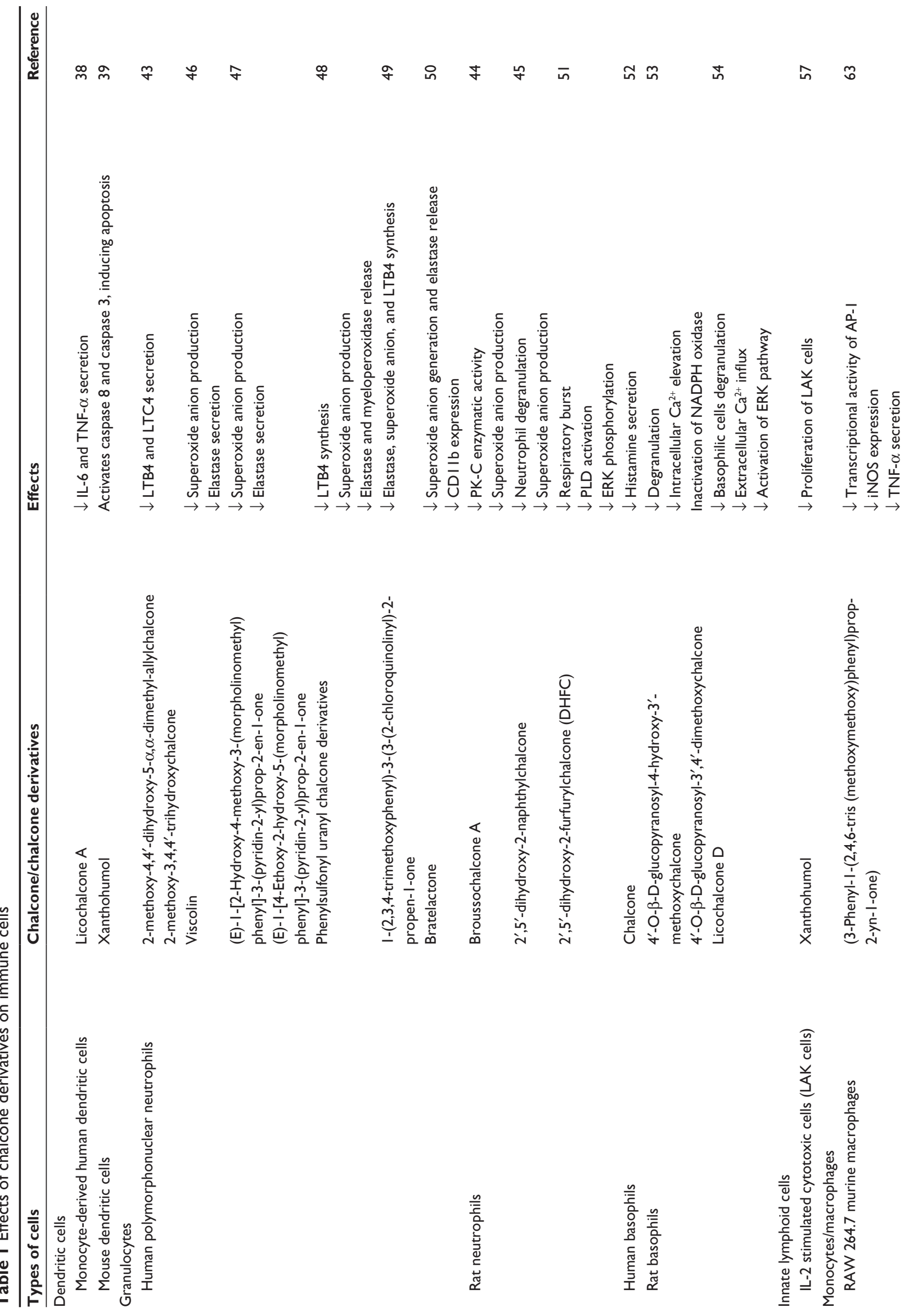


으

เิ

เ

$5 \pi k \pi$

ก

ㄴํㅇำ

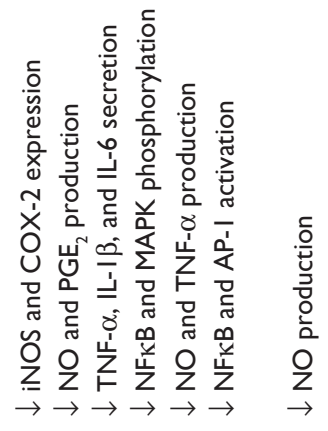

흠
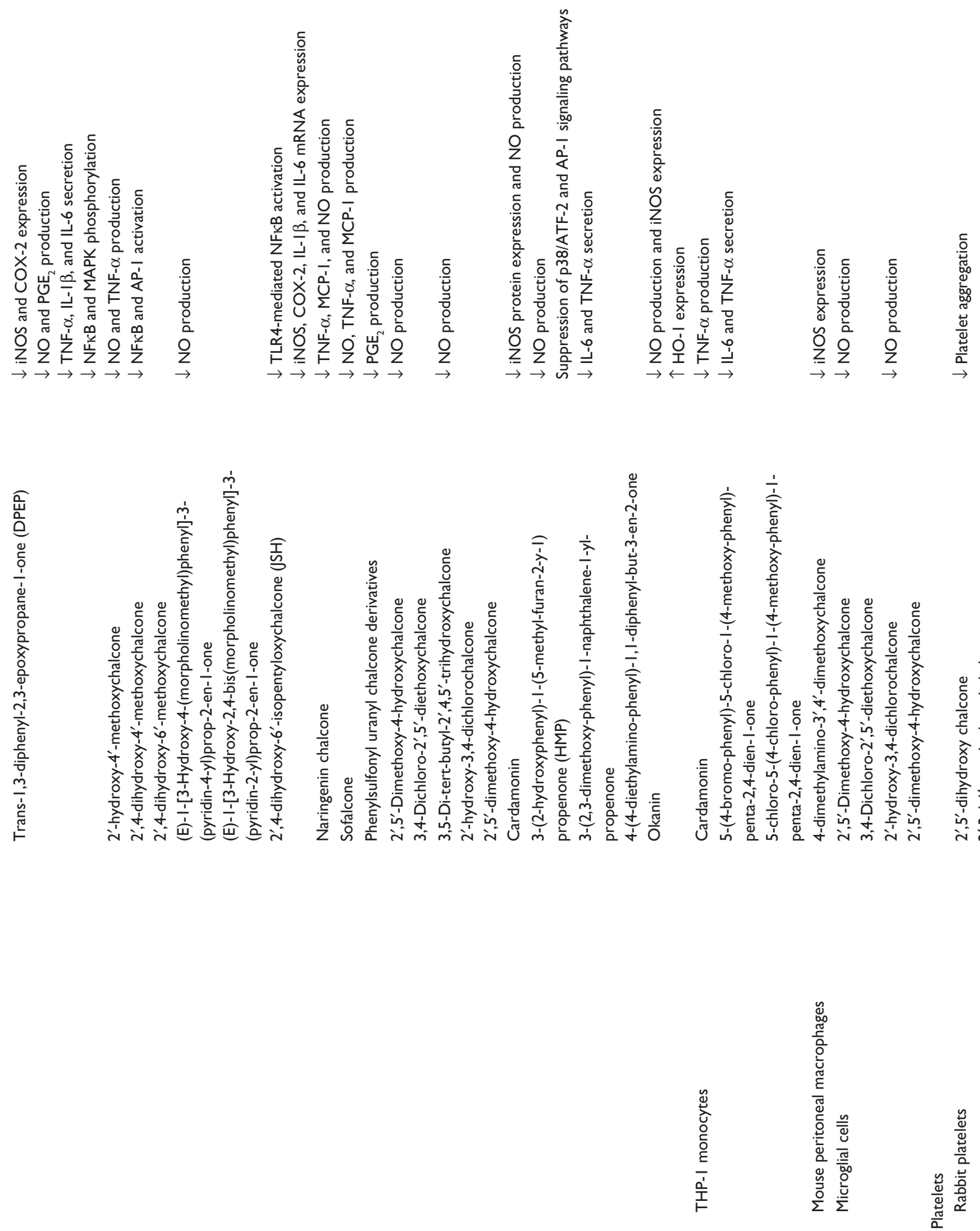


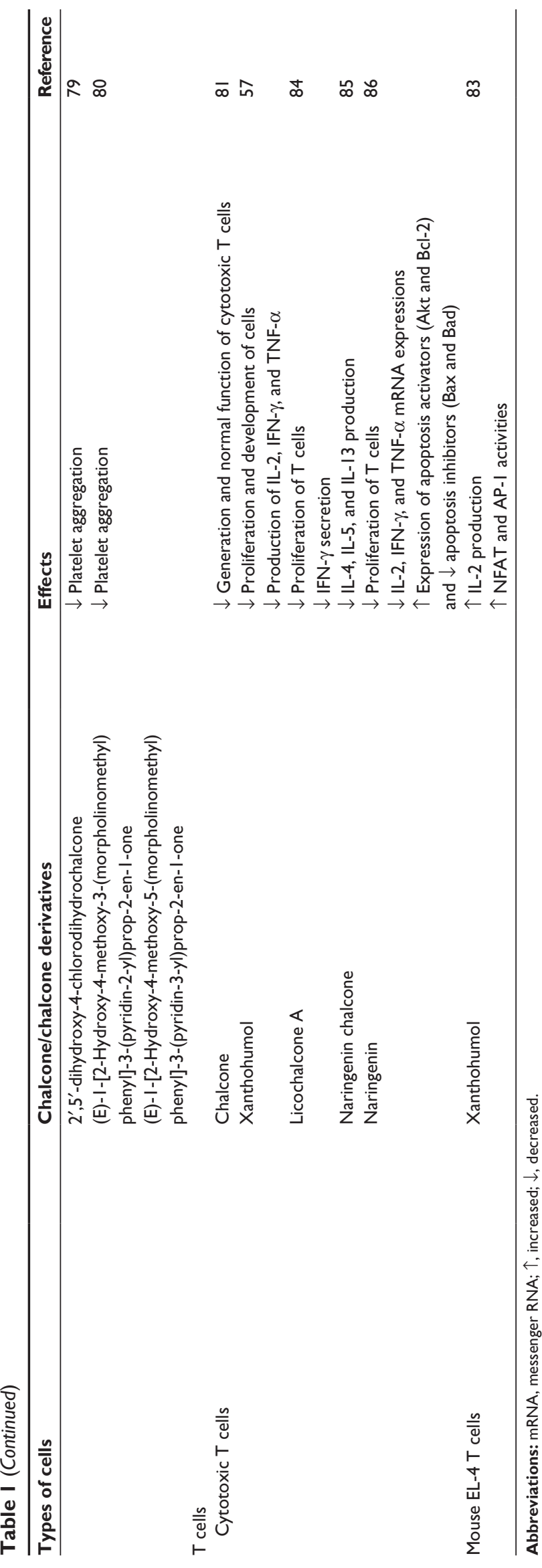

such as thymus, lymph nodes, and spleen as well as blood circulation and other tissues of the body. Dendritic cells, such as Langerhans cells in skin, initiate immune responses by capturing extracellular antigens and displaying to $T$ cells. They are activated when specific pathogen-associated molecular patterns (PAMPs) expressed by microorganisms come into contact with the cell surface pattern-recognition receptors. ${ }^{37}$ This is followed by increased expression of B7 costimulatory molecules, such as CD80 and CD86, on the dendritic cell surface. These costimulatory molecules are pivotal to facilitate lymphocyte activation. ${ }^{21}$ Activated dendritic cells will then introduce antigen expressed on the MHC molecules to $\mathrm{T}$ cells in local draining lymph nodes. MHCs can be grouped into class I (also termed human leukocyte antigen [HLA] A, B and C), which are expressed on all nucleated cells, or class II (also termed HLA, DP, DQ, and DR), which are presented on certain immune cells, including macrophages, dendritic cells, and B cells. The antigen is cleaved into short peptides prior to presentation by MHC molecules on dendritic cells. Dendritic cells are efficient in activating naïve $\mathrm{T}$ cells that have no immunologic memory.

\section{Effects of chalcones in dendritic cells}

As dendritic cells play a central role in initiating cell-mediated immunity, alteration of dendritic cell activities in individuals with immune diseases might be helpful to ameliorate the unwanted condition. Licochalcone A (2) was reported to be able to suppress IL- 6 and TNF- $\alpha$ secretion in immature monocyte-derived human dendritic cells stimulated with lipopolysaccharide (LPS). ${ }^{38}$ Xanthohumol (3), which can be found in beer, was documented to induce the translocation of acid sphingomyelinase from the intracellular compartment onto the cell surface, triggering the formation of ceramide, which then activates caspase 8 and caspase 3 . The activation of these molecules was shown to stimulate DNA fragmentation and destruction of intracellular proteins, leading to apoptosis in mice dendritic cells. ${ }^{39}$ Apoptotic activity of xanthohumol in dendritic cells might be a potential target function in improving inflammation.<smiles>C=CC(C)(C)c1cc(/C=C/C(=O)c2ccc(O)cc2)c(OC)cc1O</smiles>

(2) 


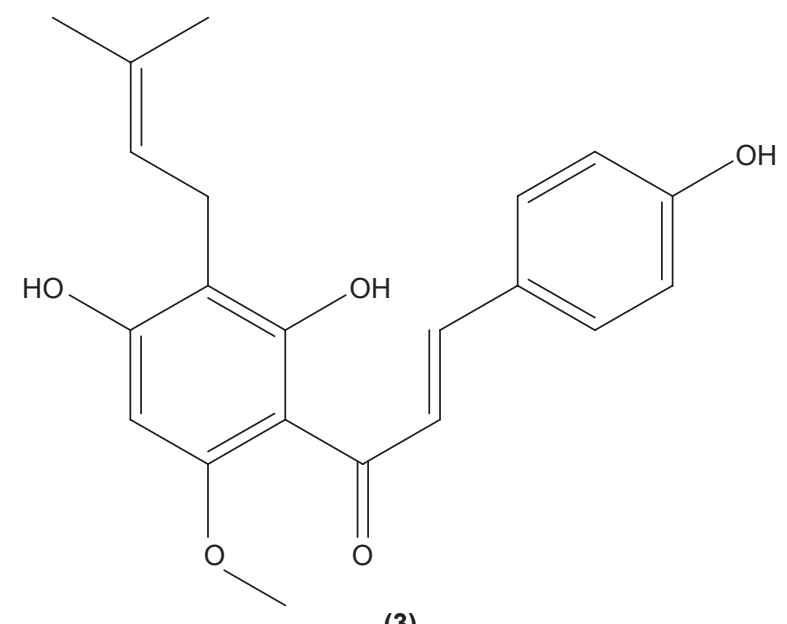

(3)

\section{Granulocytes}

Granulocytes are a group of cells with the presence of granules in their cytoplasm, including neutrophils, eosinophils, basophils, and mast cells. Neutrophils are important for innate immune response. These cells provide rapid response and nonspecific protective effect against invading pathogens, and the exposure of antigen by APCs is not required to activate these cells. They eliminate the invading pathogens by phagocytosis, degranulation, and NADPH oxidase-dependent killing processes.$^{40}$ Recruitment of neutrophils to the target site is essential in the innate immunity. Neutrophils express L-selectin on their surface, to facilitate low-affinity adhesion of neutrophils to the endothelial surfaces. Upon stimulation by inflammatory mediators, low-affinity adherence of the neutrophils will be switched to a high-affinity interaction mediated by integrin and cell adhesion molecules, such as endothelial ICAM-1 and ICAM-2. Neutrophils can be recruited to the target site by the effect of chemokines, leukotrienes, prostaglandins (PG), and C5a. Antibody and complement opsonization facilitate the phagocytosis process by neutrophils. Receptors on neutrophils that are specific for the Fc-region of antibody, such as CD64, CD32, CD16, CD89, and CD23, can interact with antibodies bound to the surface of microorganisms, enabling the occurrence of phagocytosis. Neutrophils destroy microorganisms by the generation of ROS and granules containing antimicrobial peptides, proteins, and enzymes. ${ }^{41}$

Mast cells and basophils share many similar characteristics, but they also differ in certain functions. Expression of high-affinity receptor for IgE (FceR) can be found on both cell types. Both mast cells and basophils are essential effector cells in acute IgE-associated allergic reaction. ${ }^{42}$ However, basophils usually circulate in the peripheral blood, while mast cells are found in the connective tissue surrounding blood vessels. ${ }^{20}$ Basophils and certain mast cells can secrete IL-4 and IL-13, which may alter the production of IgE antibody. ${ }^{42}$ These cells are also essential to produce inflammatory mediators, such as histamine, PG, and leukotriene in atopic allergies. ${ }^{21}$ Eosinophils are granulocytes that possess phagocytic features and are important in eliciting immune response against parasites that are too large to be phagocytosed. Eosinophils work together with basophils and mast cells in regulating mechanisms associated with allergy and asthma. ${ }^{20}$ Activated eosinophils destroy parasites by producing cationic proteins and reactive oxygen metabolites into the extracellular fluid. Similar to basophils and mast cells, eosinophils also generate leukotriene, PG, and several cytokines. ${ }^{20}$

\section{Effects of chalcones in granulocytes}

The role of chalcone derivatives in neutrophils has been discovered in numerous studies. Early in 1988, the inhibitory effects of two chalcones on calcium-ionophore-induced LTB4 and LTC4 in human polymorphonuclear neutrophils were reported by Kimura et al in Japan. The two chalcones, namely 2 -methoxy-4,4'-dihyroxy-5- $\alpha, \alpha$-dimethylallylchalcone (2) and 2-methoxy-3,4,4'-trihydroxychalcone (4), were isolated from the Glycyrrhiza inflate Bat. ${ }^{43}$ In 1997, Broussochalcone A (5), a prenylated chalcone, which can be found in Broussonetia papyrifera, was documented by Wang et al capable of attenuating cytosolic PKC enzymatic activity as well as inhibiting superoxide anion production in phorbol myristate (PMA)-induced rat neutrophils. PKC has a role in facilitating the assembly of NADPH oxidase to membrane flavocytochromes, whilst NADPH oxidase plays a role in superoxide anion generation. ${ }^{44}$ Another study in the following year reported the inhibitory effect of $2^{\prime}, 5^{\prime}$-dihydroxy2-naphthylchalcone (6) on neutrophil degranulation and superoxide anion generation in rat neutrophils. ${ }^{45}$ In addition, viscolin (7), extracted from the mistletoe species Viscum coloratum, reduces the respiratory burst in formyl-L-methionylL-leucyl-phenylalanine (fMLP)-induced superoxide anion generation and elastase release in human neutrophils. These effects are believed to be modulated by elevating cyclic adenosine monophosphate (cAMP) in neutrophils, via the inhibition of cAMP-specific PDE degradative enzymes. ${ }^{46}$ Similarly, Mannich bases of heterocyclic chalcones, namely (E)-1-[2-hydroxy-4-methoxy-3-(morpholinomethyl)phenyl]3-(pyridin-2-yl)prop-2-en-1-one (8) and (E)-1-[4-Ethoxy2-hydroxy-5-(morpholinomethyl)phenyl]-3-(pyridin-2-yl) prop-2-en-1-one (9) inhibit the generation of superoxide anion and elastases. ${ }^{47}$ 
<smiles>COc1c(C(=O)/C=C/c2ccc(O)cc2)ccc(O)c1O</smiles>

(4)<smiles>CC(C)=CCc1cc(C(=O)/C=C/c2ccc(O)cc2)c(O)cc1O</smiles>

(5)<smiles>O=C(/C=C/c1ccc2ccccc2c1)c1cc(O)ccc1O</smiles>

(6)<smiles>COc1cc(CCCc2c(OC)cc(O)c(OC)c2OC)ccc1O</smiles><smiles>COc1ccc(C(=O)/C=C/c2ccccn2)c(O)c1CN1CCOCC1</smiles><smiles>CCOc1cc(O)c(C(=O)/C=C/c2ccccn2)cc1CN1CCOCC1</smiles>

(9)

LTB4 generated in the reaction catalyzed by 5-LO may enhance neutrophil migration and chemotaxis in inflammatory conditions. Phenylsulfonyl uranyl chalcone derivatives were found to reduce the synthesis of LTB4 by suppressing 5-LO activity in human neutrophils. Meanwhile, these compounds also inhibited generation of superoxide anion in PMA-stimulated neutrophils, as well as elastase and myeloperoxidase production in cytochalasin B- and fMLP-induced neutrophils. ${ }^{48}$ The synthetic chalcone derivative 1-(2,3,4-trimethoxyphenyl)-3-(3-(2chloroquinolinyl)-2-propen-1-one (TQ) (10) was found to exhibit anti-inflammatory property, by suppressing the production of elastase and superoxide anion, and LTB4-release in human neutrophils. ${ }^{49} \mathrm{~A}$ study conducted by $\mathrm{Wu}$ et al in 2013 revealed that bratelactone (11), a novel chalcone isolated from Fissistigma bracteolatum, significantly attenuated superoxide anion generation, ROS production, and elastase release in fMLP-stimulated human neutrophils. However, it had no direct effect on superoxide anion scavenging activity or on elastase enzymatic activities. $\mathrm{Ca}^{2+}$ signaling is a key factor for activation of human neutrophils. Upon stimulation, $\mathrm{Ca}^{2+}$ is released from intracellular endoplasmic reticulum storage, where the depletion of this $\mathrm{Ca}^{2+}$ storage will, in turn, initiate influx of $\mathrm{Ca}^{2+}$ via store-operated $\mathrm{Ca}^{2+}$ entry (SOCE). Bratelactone ameliorates inflammation by inhibiting SOCE instead of activating the cAMP signaling pathway. This compound also was shown to significantly reduce $\mathrm{CD} 11 \mathrm{~b}$, an integrin expressed in human neutrophils stimulated with fMLP and cytochalasin B, thus ameliorating the inflammatory condition by preventing the neutrophils migration into tissues. ${ }^{50}$<smiles>COc1ccc(C(=O)/C=C/c2cc3ccccc3nc2Cl)c(OC)c1OC</smiles>

(10) 


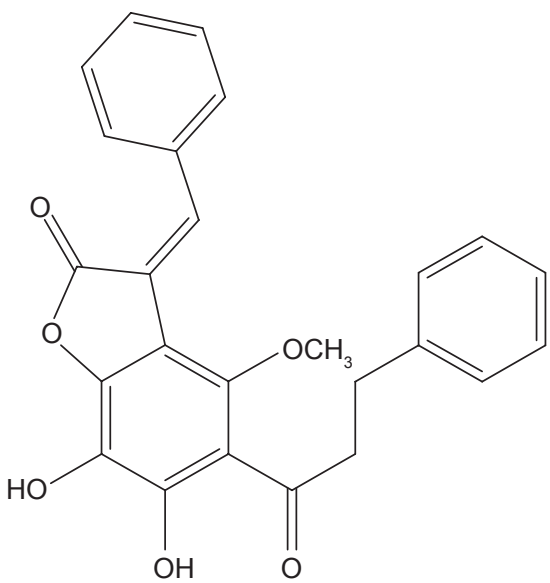

(11)

In another study, 2',5'-dihydroxy-2-furfurylchalcone (DHFC) (12) was reported to concentration-dependently inhibit respiratory burst in neutrophils stimulated by fMLP. DHFC also exhibited slight inhibition of PI3K activation, which is essential for the activation of NADPH oxidase by fMLP, and moderate suppression of phosphorylation of PKB (Akt), a serine/threonine protein kinase that is an effector of PI3K. The significant inhibitory effect of DHFC is likely due to its suppression of PLD activation, by disrupting PKC, Rho A, and ARF membrane association in fMLP-induced rat neutrophils. PLD is a key factor for the formation of phosphatidic acid, a compound that may contribute to NADPH oxidase activation. Meanwhile, DHFC exerted a greater extent of inhibition on ERK phosphorylation than the p38 MAPK phosphorylation in fMLP-stimulated neutrophils. ${ }^{51}$

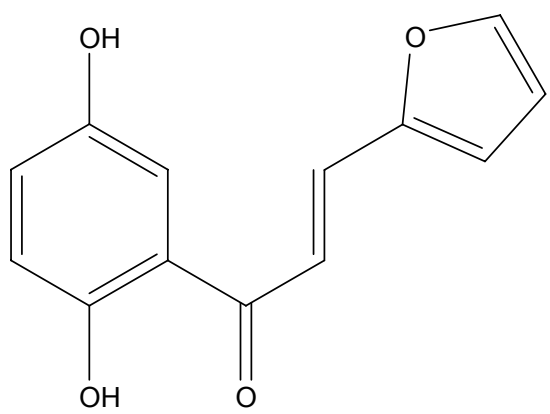

(12)

Chalcone was shown to exhibit inhibitory activity on human basophil histamine secretion induced by several agents, such as antigen, anti-IgE, concanavalin, ionophore, formyl-methionyl-leucyl-phenylalanine, and tetradecanoylphorbol acetate. ${ }^{52}$ Two chalcone derivatives, namely 4'-O- $\beta$-D-glucopyranosyl-4-hydroxy-3'-methoxychalcone (13) and 4'-O- $\beta$-D-glucopyranosyl-3', $4^{\prime}$-dimethoxychalcone (14), isolated from the aerial parts of the Brassica rapa $\mathrm{L}$. hidabeni turnip, were reported to be able to inhibit antigenstimulated degranulation in rat RBL-2H3 basophilic cells, suggesting the role of chalcone derivatives as potential agents to improve the allergic reaction. The inhibitory effect of these chalcone derivatives was attributed to their ability to suppress intracellular $\mathrm{Ca}^{2+}$ elevation by inhibiting ROS production via inactivation of NADPH oxidase..$^{53}$ Licochalcone D (15), a chalcone derivative isolated from the root Xinjiang liquorice, has demonstrated a suppression effect on the degranulation of RBL-2H3 cells by inhibiting extracellular $\mathrm{Ca}^{2+}$ influx and activation of the ERK pathway. ${ }^{54}$<smiles>[R]c1ccc(/C=C/C(=O)c2ccc(OC3OC(CO)C(O)C(O)C3O)c(OC)c2)cc1</smiles>

(13): $\mathrm{R}=\mathrm{OH}$

(14): $\mathrm{R}=\mathrm{OMe}$<smiles>COc1c(/C=C/C(=O)c2ccc(O)c(CC=C(C)C)c2)ccc(O)c1O</smiles>

(15)

\section{Innate lymphoid cells (ILCs)}

ILCs define a group of lymphocytes that have important roles in rapid cytokine-dependent innate immunity, inflammation, and tissue remodeling. Despite that ILCs do not express rearranged antigen-specific receptors, they share similar transcription factor profiles and cytokine generation patterns as $\mathrm{CD} 4^{+}$ $\mathrm{T}$ cells. Thus, these cells display similar functions as the $\mathrm{CD} 4^{+}$Th cell of adaptive immunity. ILCs can be divided into three main groups based on the particular transcription factor expression and distinct patterns of cytokine production. Group 1 ILCs express transcription factor T-bet, and IFN- $\gamma$ which is mediated by IL-12, and raise the immune response against intracellular pathogens and tumors. One of the most prominent cells in group $1 \mathrm{ILCs}$ is the NK cell. ${ }^{55} \mathrm{NK}$ cells are similar to the $\mathrm{CD}^{+} \mathrm{T}$ cells, which function to destroy tumor cells and viral-infected cells. NK cells exhibit Fc $\gamma$ Rs that recognize and interact with IgG-coated target cells, therefore eliminating the target cells by a process termed antibody-dependent cellular cytotoxicity. NK cells are also equipped with another 
recognition system that involves killer activating receptors and killer inhibitory receptors to regulate the killing mechanism of these cells. The killer activating receptors recognize different molecule displays on all nucleated cells, while killer inhibitory receptors interact with the MHC I molecules, which are normally present on all nucleated cells. Failure in transmission of the inhibitory signal by the killing inhibitory receptors upon interaction with the MHC I molecules can trigger killing mechanism of NK cells to destroy the target cells. NK cells destroy the target cells by inserting a pore-forming molecule, termed perforin, into the target cell membrane, followed by injection of cytotoxic granzymes to induce apoptosis. Group 2 ILCs express transcription factor GATA-3 as well as secrete IL-5, IL-9, and IL-13, mediated by IL-25, IL-33, and TSLP. These cells have an essential role in promoting allergic inflammation and immune responses against helminth infection. Group 3 ILCs express ROR $\gamma \tau$. These cells generate IL-17A and IL-22 when stimulated by IL-23 and IL-1 $\beta$. These cells demonstrate important functions in regulating the intestinal epithelial barrier and tissue inflammation, and directing immune responses against extracellular bacteria. It has been suggested that ILCs contribute to early cytokine generation owing to their quick response to stimulation. ${ }^{56}$

\section{Effects of chalcones in ILCs}

The roles of ILCs in the immune system were not wellunderstood in the early development of immunology. The discovery of these cells prompted investigators to develop new interventions against immune diseases, owing to their functions as innate immunity effectors. Xanthohumol (3), the main prenylated chalcone, which can be found in hops (Humulus lupulus L.), was reported to be able to significantly inhibit production of nonspecific IL-2 stimulated cytotoxic cells (LAK cells) from mice spleen cells. ${ }^{57}$ It was suggested that the antiproliferative activity of xanthohumol (3) may be attributed to the inhibition of the intracellular NFKB signaling pathway. Xanthohumol was found to inhibit the activation of the NFKB pathway by suppressing IKK activation, through the modification of the cysteine residue of IKK by the Michael addition. ${ }^{58}$ However, the investigation of the effect of chalcone and its derivatives in ILCs is still lacking.

\section{Monocytes/macrophages}

Monocytes and macrophages are key components of the innate immune system. These cells originate from a common myeloid precursor and are recruited to sites of injury or infection. ${ }^{59}$ Basically, monocytes can be classified as "classical" and "nonclassical" based on differential expression of antigenic markers and recognized biological responses. The majority of monocytes are categorized as classical and express CD64. The nonclassical subpopulation is characterized by the expression of CD16. ${ }^{60}$ Monocytes patrol in the blood, bone marrow, and spleen, and do not proliferate under normal condition. However, they can differentiate into inflammatory macrophages during inflammation. ${ }^{59}$ Macrophages serve as phagocytes in innate immunity to engulf foreign substances and as antigens presenting cells to stimulate T cells. They manage to distinguish "foreign" molecules from "self" molecules by expressing receptors that recognize carbohydrates that are not normally present on the cells of vertebrates, such as mannose. ${ }^{61}$ The phagocytic activity of macrophages is facilitated by the coating of invading microorganisms with antibodies, complement, or both. In macrophages, the phagocytosed microorganisms are destroyed by a number of toxic reactive oxygen metabolites, such as superoxide anion, hydroxyl radicals, hypochlorous acid, nitric oxide, antimicrobial cationic proteins, and lysozyme. Meanwhile, macrophages also eliminate the body's dead or dying cells through recognition of molecules expressed on the surface of necrotic cells or apoptotic cells. ${ }^{62}$ They are long-lived cells, unlike the short-lived neutrophils, although both cell types are phagocytes. Macrophages that reside in different tissues of the body are denominated with different names. For example, macrophages existing in the liver are called Kupffer cells, whereas those residing in the connective tissue are known as histiocytes, and the macrophages present in the central nervous system are known as microglial cells. ${ }^{20}$

\section{Effects of chalcones in monocytes/macrophages}

Chalcone derivatives may perform potential anti-inflammatory activity in monocytes and macrophages. In 2009, Park et al investigated the effect of 3-phenyl-1-(2,4,6tris(methoxymethoxy)phenyl)prop-2-yn-1-one (16), a chalcone derivative, in murine RAW 264.7 macrophages and suggested that this compound could inhibit the transcriptional activity of AP-1 by suppressing the expression of certain AP-1 protein subunits induced by LPS, but it did not affect $N F \kappa B$ gene expression. They also revealed the significant pretreatment and posttreatment suppression effect of chalcone derivative on nitric oxide (NO) production, owing to its inhibition of iNOS expression in RAW 264.7 macrophages. Suppression of LPS-induced TNF- $\alpha$ secretion in a dosedependent manner by a chalcone derivative was also reported by the researchers, showing the anti-inflammatory potential of the compound. ${ }^{63}$ 
<smiles>COCOc1cc(OCOC)c(C(=O)C#Cc2ccccc2)c(OCOC)c1</smiles>

Concordantly, another chalcone derivative, known as trans-1,3-diphenyl-2,3-epoxypropane-1-one (DPEP) (17), was documented to be able to inhibit iNOS and COX-2 expression induced by LPS, thus reducing the production of $\mathrm{NO}$ and $\mathrm{PGE}_{2}$ in RAW 264.7 macrophages. Meanwhile, DPEP also exerted anti-inflammatory activity by reducing the production of proinflammatory cytokines, such as TNF- $\alpha$, IL- $1 \beta$, and IL- 6 . The pharmacological activities of DPEP in several inflammatory mediators were attributed to its ability to block NFKB activities as well as MAPK phosphorylation, both of which play pivotal roles in the initiation and development of inflammation. ${ }^{10} \mathrm{On}$ the other hand, Ban et al revealed that LPS-induced NO and TNF- $\alpha$ production in RAW 264.7 macrophages could be inhibited by chalcone derivatives, namely $2^{\prime}$-hydroxy- $4^{\prime}$-methoxychalcone (18), 2',4-dihydroxy-4'-methoxychalcone (19), and 2',4dihydroxy-6'-methoxychalcone (20). The mechanism underlying this inhibitory effect of chalcone derivatives is likely the suppression of NFKB and AP-1 activation that are essential for iNOS and cytokine gene expression. ${ }^{64}$ The inhibition of NO production by (E)-1-[3-Hydroxy-4-(morpholinomethyl) phenyl]-3-(pyridin-4-yl)prop-2-en-1-one (21) and (E)-1-[3Hydroxy-2,4-bis(morpholinomethyl)phenyl]-3-(pyridin-2-yl) prop-2-en-1-one (22) in LPS- and IFN- $\gamma$-stimulated RAW 264.7 macrophages has also been reported in a recent study. ${ }^{47}$<smiles>O=C(c1ccccc1)C1(c2ccccc2)OC1c1ccccc1</smiles><smiles>[R]c1ccc(/C=C/C(=O)c2c([R])cc([R])cc2O)cc1</smiles>

(18): $\mathbf{R}_{1}^{\prime}=\mathrm{OCH}_{3}, \mathbf{R}_{2}^{\prime}=\mathrm{H}, \mathbf{R}_{1}=\mathrm{H}$ (19): $\mathbf{R}_{1}^{\prime}=\mathrm{OCH}_{3}, \mathbf{R}_{2}^{\prime}=\mathrm{H}, \mathrm{R}_{1}=\mathrm{OH}$ (20): $\mathrm{R}_{1}^{\prime}=\mathrm{H}, \mathrm{R}_{2}^{\prime}=\mathrm{OCH}_{3}, \mathrm{R}_{1}=\mathrm{OH}$<smiles>O=C(/C=C/c1ccncc1)c1ccc(CN2CCOCC2)c(O)c1</smiles>

(21)<smiles>O=C(/C=C/c1ccccn1)c1ccc(CN2CCOCC2)c(O)c1CN1CCOCC1</smiles>

(22)

In cultured peritoneal macrophages isolated from mice, 4-dimethylamino-3',4'-dimethoxychalcone (23) was documented to be able to downregulate iNOS expression, inhibiting cytotoxic effects of the superoxide radical. ${ }^{65}$ TLR-4 is expressed in macrophages and is essential for interaction with endotoxin or LPS in order to elicit innate immune response. A chalcone derivative, $2^{\prime}$,4-dihydroxy-6'-isopentyloxychalcone (JSH) (24) was found to inhibit TLR4-mediated NFKB activation in LPS-induced macrophages by acting competitively with LPS on MD-2, a subunit that forms a receptor complex with TLR4 to recognize endotoxin. This in turn prevents the activation of NFKB activity and further suppresses messenger (m)RNA expression for iNOS, COX-2, IL-1 $\beta$, and IL-6. ${ }^{66}$<smiles>COc1ccc(/C=C/C(=O)c2ccc(N(C)C)cc2)cc1OC</smiles><smiles>CC(C)CCOc1cccc(O)c1C(=O)/C=C/c1ccc(O)cc1</smiles>

(24) 
Hirai et al revealed that naringenin chalcone (25) exerted its anti-inflammatory action by inhibiting LPS-induced TNF- $\alpha$, MCP-1, and NO production in RAW 264.7 macrophages in a dose-dependent manner. The investigators also reported that the production of proinflammatory mediators was significantly inhibited by naringenin chalcone in RAW 264.7 macrophages cocultured with adipose tissue. ${ }^{67}$ Sofalcone (20-carboxymethoxy-4,40-bis(3-methyl-2-butenyloxy) chalcone) (26) displayed its anti-inflammatory property by suppressing the production of LPS-induced NO, TNF- $\alpha$, and MCP-1 in a coculture system consisting of RAW 264.7 macrophages and adipocytes. The suppressive effect of sofalcone on NO production is achieved by inducing HO-1 expression, an enzyme responsible for regulating the inflammatory condition. ${ }^{68}$ In an earlier study, phenylsulfonyl uranyl chalcone derivative was found capable of inhibiting LPSinduced $\mathrm{PGE}_{2}$ production in RAW 264.7 macrophages. The inhibitory effect of chalcone derivatives on $\mathrm{PGE}_{2}$ production is likely due to its selective inhibition of COX-2 activity. ${ }^{48}$ Moreover, 2',5'-dimethoxy-4-hydroxychalcone (27) and 3,4-dichloro-2',5'-diethoxychalcone (28) were reported to be able to inhibit LPS-induced NO production in RAW 264.7 macrophages and microglial cells. ${ }^{69}$<smiles>O=C(/C=C/c1ccc(O)cc1)c1c(O)cc(O)cc1O</smiles>

(25)<smiles>CC(C)=CCOc1ccc(/C=C/C(=O)c2ccc(OCC=C(C)C)cc2OC(=O)O)cc1</smiles>

(26)<smiles>[R]c1ccc([R4])c(C(=O)/C=C/c2ccc([R])c([R])c2)c1</smiles>

(27): $\mathbf{R}_{1}^{\prime}=\mathrm{OMe}, \mathrm{R}_{5}^{\prime}=\mathrm{OMe}, \mathrm{R}_{3}=\mathrm{H}, \mathrm{R}_{4}=\mathrm{OH}$ (28): $\mathbf{R}_{2}^{\prime}=\mathrm{OEt}, \mathrm{R}_{5}^{\prime}=\mathrm{OEt}, \mathrm{R}_{3}^{\prime}=\mathrm{Cl}, \mathrm{R}_{4}=\mathrm{Cl}$
Likewise, three synthetic chalcones, 3,5-di-tert-butyl-2', 4,5'-trihydroxychalcone (29), 2'-hydroxy-3,4-dichlorochalcone (30), and 2',5'-dimethoxy-4-hydroxychalcone (31) are documented to inhibit NO accumulation from LPS-stimulated RAW 264.7 macrophages in a dose-dependent manner. In addition, the second and third compounds were also reported to show inhibition of NO production in LPS- and IFN- $\gamma$-stimulated N9 microglial cells. ${ }^{70} 2^{\prime}, 4^{\prime}$-dihydroxy-6'-methoxychalcone, also known as cardamonin (32), a chalcone derivative isolated from Artemisia absinthium L., was found to exhibit its inhibitory effect on TNF- $\alpha$ production in THP-1 monocytic cells upon LPS stimulation. In addition, cardamonin was shown to suppress iNOS protein expression and NO production induced by LPS or IFN- $\gamma$ in RAW 264.7 macrophages. However, cardamonin did not affect the activation of LPS-stimulated MAPK phosphorylation, p65 phosphorylation, and IкB $\alpha$ degradation in both THP-1 monocytes and RAW 264.7 macrophages, but it did interfere with LPS-induced binding of NFKB to DNA. This suggested that the cardamonin exhibited its anti-inflammatory properties by preventing the binding of NFKB to the DNA instead of suppressing the NF $\kappa \mathrm{B}$ signaling cascade activation. ${ }^{71}$ Another chalcone derivative, 3-(2-hydroxyphenyl)-1-(5-methyl-furan-2y-1)propenone (HMP) (33), was reported to display significant concentration-dependent inhibition on NO generation in RAW 264.7 macrophages induced by LPS, owing to its suppression of p38/ATF-2 and AP-1 signaling pathways. ${ }^{72}$ 3-(2,3-dimethoxyphenyl)-1-naphthalene-1-yl-propenone (34) and 4-(4-diethylamino-phenyl)-1,1-diphenyl-but-3-en-2-one (35) were also reported to suppress the secretion of IL- 6 and TNF- $\alpha$ in LPS-induced RAW 264.7 macrophages. ${ }^{73}$ Two $\beta$-chlorovinyl chalcones, with chemical structures of 5-(4-bromo-phenyl)-5chloro-1-(4-methoxy-phenyl)-penta-2,4-dien-1-one (36) and 5-chloro-5-(4-chloro-phenyl)-1-(4-methoxy-phenyl)-1-penta2,4-dien-1-one (37), also exhibited significant suppression of LPS-induced IL-6 and TNF- $\alpha$ production in THP-1 cells. ${ }^{74}$ Okanin (38), a natural chalcone isolated from the genus Bidens and 3-penten-2-one were found to be able to suppress LPSinduced NO production and iNOS expression in RAW264.7 macrophages through upregulation of $\mathrm{HO}-1$ expression. ${ }^{75}$

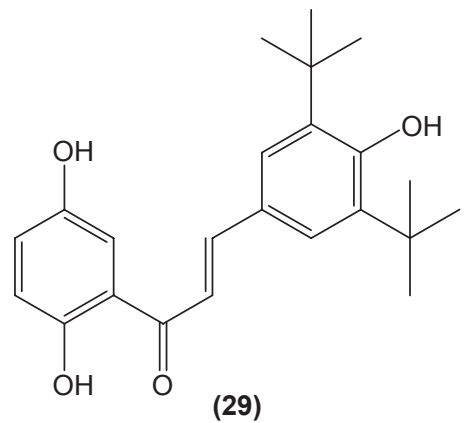


<smiles>O=C(/C=C/c1ccc(Cl)c(Cl)c1)c1ccccc1O</smiles>

(30)<smiles>COc1ccc(OC)c(C(=O)/C=C/c2ccc(O)cc2)c1</smiles>

(31)<smiles>COc1cc(O)cc(O)c1C(=O)/C=C/c1ccccc1</smiles>

(32)<smiles>Cc1ccc(C(=O)/C=C/c2ccccc2O)o1</smiles>

(33)<smiles>COc1cccc(/C=C/C(=O)c2cccc3ccccc23)c1OC</smiles><smiles>CCN(CC)c1ccc(/C=C/C(=O)C(c2ccccc2)c2ccccc2)cc1</smiles><smiles>[R]c1ccc(C(=O)/C=C/C=C(\Cl)c2ccc([R])cc2)cc1</smiles>

(36): $\mathbf{R}_{1}^{\prime}=\mathrm{OCH}_{3}, \mathbf{R}_{1}^{\prime}=\mathrm{Br}$

(37): $\mathrm{R}_{1}^{\prime}=\mathrm{OCH}_{3}, \mathrm{R}_{1}^{\prime}=\mathrm{Cl}$<smiles>O=C(/C=C/c1ccc(O)c(O)c1)c1ccc(O)c(O)c1O</smiles>

\section{Platelets}

Platelets are anucleated cells that have significant role in the coagulation mechanism of human body. These cells originated from large progenitor cells in the bone marrow, known as megakaryocytes. Platelets are essential players in hemostatic functions as their granules contain numerous hemostatic mediators, such as platelet-derived growth factor, adenosine diphosphate (ADP), and thromboxane $\mathrm{A}_{2}$. In the immune system, platelets express a number of immunomodulatory molecules, such as P-selectin, TLRs, CD40L, IL-1 $\beta$, and TGF- $\beta$, that may affect both innate and adaptive immunity. ${ }^{76}$ Platelets provide innate immunity by engulfing intruding pathogens, producing antimicrobial peptides in response to platelet activation, and by secreting proinflammatory cytokines, such as IL-1, to regulate the immune response. 
Complement receptors can also be found on platelets, suggesting platelets are essential in removing immune complexes comprised of antigen, antibody, and complement. ${ }^{21}$ Activated platelets also express CD40L, which contributes to class switching of immunoglobulin and improved $\mathrm{CD} 8^{+}$ T cell function during viral infection. ${ }^{77}$ Platelets also express receptor ligands, such as CD40 and CD154, which enhance interaction between lymphocytes and APCs. ${ }^{76}$

\section{Effects of chalcones in platelets}

Chalcone derivatives with different variation of substituents have demonstrated their ability to inhibit arachidonic acidinduced and collagen-induced platelet aggregation in rabbit platelets. 2',5'-dihydroxy (39) and 2',3,4,4'-tetrahydroxyl (40) chalcones were shown to be able to suppress adrenaline-induced secondary platelet aggregation in human platelet-rich plasma. ${ }^{78}$ Concordantly, a study reported that 2',5'-dihydroxy-4-chlorodihydrochalcone (41) may inhibit platelet aggregation induced by several mediators, such as collagen, arachidonic acid, adrenaline, and platelet-activating factor. ${ }^{79}$ A more recent study conducted by Reddy et al also demonstrated the potent inhibitory properties of O-prenylated and O-allylated chalcone derivatives, on ADP-induced and collagen-induced platelet aggregation. Mannich bases of heterocyclic chalcones, such as (E)-1-[2-Hydroxy-4methoxy-3-(morpholinomethyl)phenyl]-3-(pyridin-2-yl) prop-2-en-1-one (42) and (E)-1-[2-Hydroxy-4-methoxy-5(morpholinomethyl)phenyl]-3-(pyridin-3-yl)prop-2-en-1one (43), were also shown to possess an inhibitory effect on collagen-induced or ADP-induced platelet aggregation. Mannich bases of heterocyclic chalcones with a pyridyl ring-B moiety may present the strongest inhibitory effects. ${ }^{80}$<smiles>O=C(/C=C/c1ccccc1)c1cc(O)ccc1O</smiles>

(39)<smiles>O=C(/C=C/c1ccc(O)c(O)c1)c1ccc(O)cc1O</smiles>

(40)

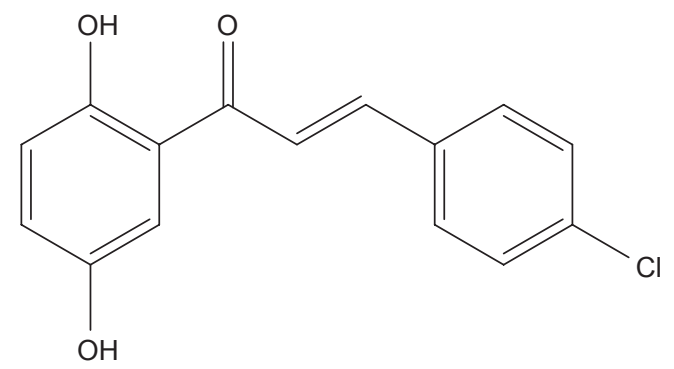

(41)

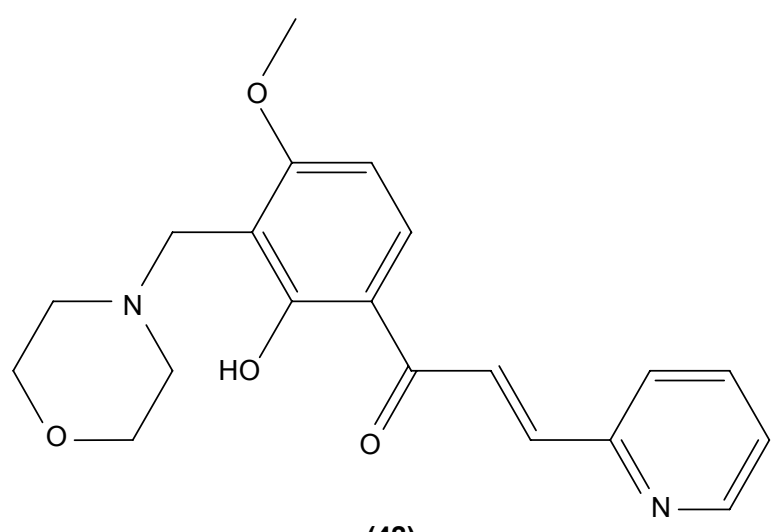

(42)

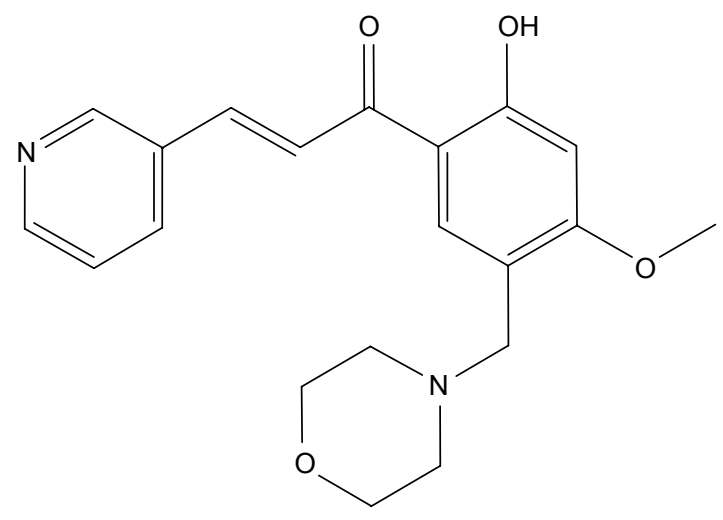

(43)

\section{T cells}

$\mathrm{T}$ cells are lymphocytes derived from hematopoietic stem cells that have principal role in conducting the cell-mediated adaptive immune response. These cells express TCR on their surface to recognize specific antigens processed by APCs, such as dendritic cells, macrophages, and fibroblasts. ${ }^{20} \mathrm{Naïve}$ lymphocytes proliferate and differentiate into effector $\mathrm{T}$ and $\mathrm{B}$ cells and memory $\mathrm{T}$ and $\mathrm{B}$ cells upon first stimulation by antigens displayed by APCs. Effector cells function to kill infected cells or malignant cells, while memory $\mathrm{T}$ cells produce a more ready response when exposed for the second time to the same antigen. ${ }^{13}$ Exposure of antigen fragments on 
the MHC molecules of APCs to T cells leads to the activation of $\mathrm{T}$ cells. The $\mathrm{MHC}$-antigen complex stimulates $\mathrm{T}$ cells to generate cytokines, which initiate the immune response. Activated T cells differentiate into either cytotoxic $\mathrm{T}$ cells $\left(\mathrm{CD} 8^{+}\right.$cells) or Th cells $\left(\mathrm{CD} 4^{+}\right)$. Cytotoxic T cells participate in the destruction of infected cells and are activated by the interaction of TCR-CD3 complex with peptide-bound MHC I molecules. These effector cells undergo clonal expansion to produce more cytotoxic $\mathrm{T}$ cells, which kill infected cells by secreting perforin, granzyme, and granulysin.

Th cells have no direct killing activity in the infected cells. They execute an immune response by directing other immune cells to act against pathogen-infected cells. They are stimulated by the interaction of TCR with antigen bound to MHC II molecules. Activated Th cells secrete numerous cytokines that manipulate the activity of other cell types. Antigen presentation by APCs can give rise to two types of Th cells, namely Th1 cells and Th2 cells. Th1 cells contribute to the production of IFN- $\gamma$, which in turn, promotes the bactericidal activities of macrophages as well as stimulating the production of antibody by B cells. Th2 cells secrete IL-4, IL-5, and IL-13, which function to activate or recruit IgE-producing B cells, mast cells, and eosinophils. The Th1 response is characterized by the production of IFN- $\gamma$, which activates the bactericidal activities of macrophages, and other cytokines that induce B cells to make opsonizing (coating) and neutralizing antibodies. The Th2 response is characterized by the release of cytokines (IL-4, IL-5, and IL-13), which are involved in the activation and/or recruitment of immunoglobulin E ( $\operatorname{IgE})$ antibody-producing B cells, mast cells, and eosinophils. Besides the cytotoxic $\mathrm{T}$ cells and Th cells mentioned above, there are the regulatory $\mathrm{T}\left(\mathrm{T}_{\text {reg }}\right)$ cells, which are essential for suppression of the immune system and avoidance of an immune response directed against self-antigens. ${ }^{20}$

\section{Effects of chalcones in T cells}

In work investigating the role of chalcones in T cells, these were found to inhibit the generation and normal function of cytotoxic T cells from mouse spleen. ${ }^{81}$ On the other hand, Namgoong et al reported that isoliquiritigenin (44) had no effect on mitogen-induced lymphocyte proliferation and mixed lymphocyte culture from mouse spleen. ${ }^{82}$ Xanthohumol (3), described earlier, was also studied to determine its effect in $\mathrm{T}$ cells. This compound was documented to inhibit the proliferation and development of cytotoxic T cells. It also displayed significant inhibitory effect on the production of Th1 cytokines, such as IL-2, IFN- $\gamma$, and TNF- $\alpha$, through attenuation of I $\mathrm{BB} \alpha$ phosphorylation in the NF $\kappa \mathrm{B}$ signaling pathway. ${ }^{57}$ Unlike previous finding, Choi et al documented that xanthohumol concentration-dependently increased the generation of IL-2 in mouse EL-4 T cells stimulated by PMA plus ionomycin. It was suggested that xanthohumol enhanced the production of this cytokine by upregulating NFAT and AP-1 in mouse EL-4 T cells induced by PMA/ionomycin. ${ }^{83}$ Licochalcone A, isolated from Chinese liquorice, and its analogue were reported to inhibit the proliferation as well as the secretion of IFN- $\gamma$ from $\mathrm{T}$ lymphocytes stimulated by phytohemagglutinin (PHA), in a concentration-dependent manner. ${ }^{84}$

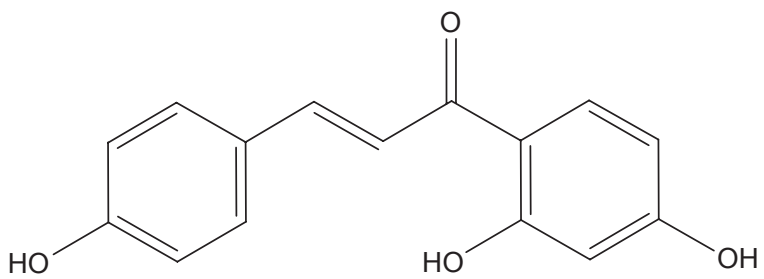

(44)

Naringenin chalcone was reported to significantly decrease production of Th2 cytokines, such as IL-4, IL-5, and IL-13, from mice splenic $\mathrm{CD}^{+} \mathrm{T}$ cells sensitized and challenged with ovalbumin. ${ }^{85}$ Naringenin (25), a chalcone, which can be found in grapefruit and other citrus fruits, was demonstrated to be able to suppress the proliferation of hapten-specific T cells, and anti-CD3- and anti-CD28-induced proliferation of mouse $\mathrm{T}$ cells. Two prominent signals are required to activate $\mathrm{T}$ cell activity - the interaction of TCR and CD3 and their coreceptors with MHC-peptide complex, as well as the interaction of B7 molecules on dendritic cells with CD28 molecules on T cells - to generate a costimulatory signal. Anti-CD3 and anti-CD28 were used in this study to stimulate and amplify $\mathrm{T}$ cells. In addition, naringenin decreased the expression of CD69 that is expressed as early activation marker in T lymphocytes. In the same study, naringenin was documented to reduce the mRNA expressions of several cytokines, including IL-2, IFN- $\gamma$, and TNF- $\alpha$. This compound was suggested to display anti-inflammatory property by causing apoptosis in activated $\mathrm{T}$ cells rather than in naïve T cells. The apoptotic effect of naringenin might be due to enhanced expressions of apoptosis activators, namely Akt and Bcl-2, as well as the inhibition of apoptosis inhibitors, such as Bax and Bad. ${ }^{86}$

\section{Conclusion}

The effects of chalcone and its derivatives in monocytes and macrophages have been studied extensively. However, the role of chalcone derivatives in other types of immune cells, 
such as B cells, dendritic cells, ILCs, and red blood cells is yet to be explored. It is hoped that this review could provide a stimulus for researchers to carry out further investigation on the pharmacological effects of chalcone derivatives in different types of immune cells.

\section{Acknowledgments}

This work was supported by the Ministry of Education through Fundamental Research Grant Scheme (grant number FRGS/2/2013/SKK01/UKM/03/7).

\section{Disclosure}

The authors report no conflicts of interest in this work.

\section{References}

1. Akira S, Uematsu S, Takeuchi O. Pathogen recognition and innate immunity. Cell. 2006;124(4):783-801.

2. Shalhoub J, Falck-Hansen MA, Davies AH, Monaco C. Innate immunity and monocyte-macrophage activation in atherosclerosis. $J$ Inflamm (Lond). 2011;8:9.

3. Davoudi S, Rasoolinegad M, Younesian M, et al. $\mathrm{CD}^{+}$cell counts in patients with different clinical manifestations of tuberculosis. Braz J Infect Dis. 2008;12(6):483-486.

4. Macdonald SH, Woodward E, Coleman MM, et al. Networked T cell death following macrophage infection by Mycobacterium tuberculosis. PLoS One. 2012;7(6): 38488.

5. Wilson HM. Macrophages heterogeneity in atherosclerosis-implications for therapy. J Cell Mol Med. 2010;14(8):2055-2065.

6. Kantarci OH, Pirko I, Rodriguez M. Novel immunomodulatory approaches for the management of multiple sclerosis. Clin Pharmacol Ther. 2014;95(1):32-44.

7. Arnson Y, Shoenfeld Y, Amital H. Intravenous immunoglobulin therapy for autoimmune diseases. Autoimmunity. 2009;42(6):553-560.

8. Frölich S, Schubert C, Bienzle U, Jenett-Siems K. In vitro antiplasmodial activity of prenylated chalcone derivatives of hops (Humulus lupulus) and their interaction with haemin. J Antimicrob Chemother. 2005;55(6):883-887.

9. Abdula AM. Synthesis, characterization and antibacterial activity of (E)-chalcone derivatives. Eur J Chem. 2013;4(3):207-210.

10. Kim KN, Ko YJ, Kang MC, et al. Anti-inflammatory effects of trans1,3-diphenyl-2,3-epoxypropane-1-one mediated by suppression of inflammatory mediators in LPS-stimulated RAW 264.7 macrophages. Food Chem Toxicol. 2013;53:371-375.

11. Ku BM, Ryu HW, Lee YK, et al. 4'-Acetoamido-4-hydroxychalcone, a chalcone derivative, inhibits glioma growth and invasion through regulation of the tropomyosin 1 gene. Biochem Biophys Res Commun. 2010;402(3):525-530.

12. Rizvi SUF, Ahmad M, Bukhari MH, et al. Anti-HIV-1 screening of (2E)-3-(2-chloro-6-methyl/methoxyquinolin-3-yl)-1-(aryl)prop-2-en1-ones. Med Chem Res. 2014;23(1):402-407.

13. Mohamad AS, Akhtar MN, Zakaria ZA, et al. Antinociceptive activity of a synthetic chalcone, flavokawin B on chemical and thermal models of nociception in mice. Eur J Pharmacol. 2010;647(1-3):103-109.

14. Bukhari SN, Lauro G, Jantan I, Bifulco G, Amjad MW. Pharmacological evaluation and docking studies of $\alpha, \beta$-unsaturated carbonyl based synthetic compounds as inhibitors of secretory phospholipase $\mathrm{A}_{2}$, cyclooxygenases, lipoxygenase and proinflammatory cytokines. Bioorg Med Chem. 2014;22(15):4151-4161.

15. Bukhari SN, Tajuddin Y, Benedict VJ, et al. Synthesis and evaluation of chalcone derivatives as inhibitors of neutrophils' chemotaxis, phagocytosis and production of reactive oxygen species. Chem Biol Drug Des. 2014;83(2):198-206.
16. Alam MS. Biological potentials of chalcones: a review. Int J Pharm Biol Sci Arch. 2012;3(6):1298-1303.

17. Rahman MA. Chalcone: a valuable insight into the recent advances and potential pharmacological activities. Chem Sci J. 2011;2011(2):CSJ-29.

18. Yadav VR, Prasad S, Sung B, Aggarwal BB. The role of chalcones in suppression of NF- $\mathrm{KB}$-mediated inflammation and cancer. Int Immunopharmacol. 2011;11(3):295-309.

19. Aderem A. Phagocytosis and the inflammatory response. J Infect Dis. 2003;187 Suppl 2:S340-S345.

20. Warrington R, Watson W, Kim HL, Antonetti FR. An introduction to immunology and immunopathology. Allergy Asthma Clin Immunol. 2011; 7 Suppl 1:S1-S8.

21. Delves PJ, Roitt IM. The immune system. New Engl J Med. 2000;343(1): 37-49.

22. Bonilla FA, Oettgen HC. Adaptive immunity. J Allergy Clin Immunol. 2010;125(2 Suppl 2):S33-S40.

23. Krampera M, Cosmi L, Angeli R, et al. Role for interferon-gamma in the immunomodulatory activity of human bone marrow mesenchymal stem cells. Stem Cells. 2006;24(2):386-398.

24. English K, Barry FP, Field-Corbett CP, Mahon BP. IFN-gamma and TNF-alpha differentially regulate immunomodulation by murine mesenchymal stem cells. Immunol Lett. 2007;110(2):91-100.

25. Liu X, Zhao M, Wu K, et al. Immunomodulatory and anticancer activities of phenolics from emblica fruit (Phyllanthus emblica L.). Food Chem. 2012;131(2):685-690.

26. Ogechukwu OE, Ogoamaka OP, Sylvester NC, et al. Steroids and triterpenoids from Eastern Nigeria mistletoe, Loranthus micranthus Linn. (Loranthaceae) parasitic on Kola acuminata with immunomodulatory potentials. Phytochem Lett. 2011;4(3):357-362.

27. Arya V, Gupta VK. A review on marine immunomodulators. Int J Pharm Life Sci. 2011;2(5):751-758.

28. Pillai AA, Levitsky J. Overview of immunosuppression in liver transplantation. World J Gastroenterol. 2009;15(34):4225-4233.

29. Thell K, Hellinger R, Schabbauer G, Gruber CW. Immunosuppressive peptides and their therapeutic applications. Drug Discov Today. 2014;19(5):645-653.

30. Robards K, Prenzler PD, Tucker G, Swatsitang P, Glover W. Phenolic compounds and their role in oxidative processes in fruits. Food Chem. 1999;66(4):401-436.

31. Bukhari SNA, Jasamai M, Jantan I. Review of methods and various catalysts used for chalcone synthesis. Mini Rev Org Chem. 2013;10(1): 73-83.

32. Yadav N, Dixit SK, Bhattacharya A, et al. Antimalarial activity of newly synthesized chalcone derivatives in vitro. Chem Biol Drug Des. 2012;80(2):340-347.

33. Lim SS, Kim HS, Lee DU. In vitro antimalarial activity of flavonoids and chalcones. Bull Korean Chem Soc. 2007;28(12):2495-2497.

34. Chen ZH, Zheng CJ, Sun LP, Piao HR. Synthesis of new chalcone derivatives containing a rhodanine-3-acetic acid moiety with potential anti-bacterial activity. Eur J Med Chem. 2010;45(12): 5739-5743.

35. Modzelewska A, Pettit C, Achanta G, Davidson NE, Huang P, Khan SR. Anticancer activities of novel chalcone and bis-chalcone derivatives. Bioorg Med Chem. 2006;14(10):3491-3495.

36. Wei H, Zhang $\mathrm{X}, \mathrm{Wu} \mathrm{G}$, et al. Chalcone derivatives from the fern Cyclosorus parasiticus and their anti-proliferative activity. Food Chem Toxicol. 2013;60:147-152.

37. Medzhitov R, Janeway CA Jr. Innate immunity: impact on the adaptive immune response. Curr Opin Immunol. 1997;9(1):4-9.

38. Kolbe L, Immeyer J, Batzer J, et al. Anti-inflammatory efficacy of Licochalcone A: correlation of clinical potency and in vitro effects. Arch Dermatol Res. 2006;298(1):23-30.

39. Xuan NT, Shumilina E, Gulbins E, Gu S, Götz F, Lang F. Triggering of dendritic cell apoptosis by xanthohumol. Mol Nutr Food Res. 2010;54 Suppl 2:S214-S224.

40. Kobayashi SD, DeLeo FR. Towards a comprehensive understanding of the role of neutrophils in innate immunity: a systems biology-level approach. Wiley Interdiscip Rev Syst Biol Med. 2009;1(3):309-333. 
41. Guichard C, Pedruzzi E, Dewas C, et al. Interleukin-8-induced priming of neutrophil oxidative burst requires sequential recruitment of NADPH oxidase components into lipid rafts. J Biol Chem. 2005;280(44): 37021-37032.

42. Wedemeyer J, Tsai M, Galli SJ. Roles of mast cells and basophils in innate and acquired immunity. Curr Opin Immunol. 2000;12(6):624-631.

43. Kimura Y, Okuda H, Okuda T, Arichi S. Effects of chalcones isolated from licorice roots on leukotriene biosynthesis in human polymorphonuclear neutrophls. Phytotherapy Res. 1988;2(3):140-145.

44. Wang JP, Tsao LT, Raung SL, Lin CN. Investigation of the inhibitory effect of broussochalcone A on respiratory burst in neutrophils. Eur J Pharmacol. 1997;320(2-3):201-208.

45. Hsieh HK, Lee TH, Wang JP, Wang JJ, Lin CN. Synthesis and antiinflammatory effect of chalcones and related compounds. Pharm Res. 1998;15(1):39-46.

46. Hwang TL, Leu YL, Kao SH, Tang MC, Chang HL. Viscolin, a new chalcone from Viscum coloratum, inhibits human neutrophil superoxide anion and elastase release via a cAMP-dependent pathway. Free Radic Biol Med. 2006;41(9):1433-1441.

47. Reddy MV, Hwang TL, Leu YL, Chiou WF, Wu TS. Inhibitory effects of Mannich bases of heterocyclic chalcones on NO production by activated RAW 264.7 macrophages and superoxide anion generation and elastase release by activated human neutrophils. Bioorg Med Chem. 2011;19(8):2751-2756.

48. Araico A, Terencio MC, AlcarazMJ,DomínguezJN, LeónC, FerrándizML Phenylsulphonyl urenyl chalcone derivatives as dual inhibitors of cyclo-oxygenase-2 and 5-lipoxygenase. Life Sci. 2006;78(25): 2911-2918.

49. De León EJ, Alcaraz MJ, Dominguez JN, Charris J, Terencio MC. 1-(2,3,4-trimethoxyphenyl)-3-(3-(2-chloroquinolinyl))-2-propen-1-one, a chalcone derivative with analgesic, anti-inflammatory and immunomodulatory properties. Inflamm Res. 2003;52(6):246-257.

50. Wu YC, Sureshbabu M, Fang YC, et al. Potent inhibition of human neutrophil activations by bractelactone, a novel chalcone from Fissistigma bracteolatum. Toxicol Appl Pharmacol. 2013;266(3):399-407.

51. Wang JP, Chang LC, Hsu MF, Lin CN. The blockade of formyl peptide-induced respiratory burst by $2^{\prime}, 5^{\prime}$-dihydroxy-2-furfurylchalcone involves phospholipase D signaling in neutrophils. Naunyn Schmiedebergs Arch Pharmacol. 2003;368(3):166-174.

52. Middleton E, Drzewiecki G. Flavonoid inhibition of human basophil histamine release stimulated by various agents. Biochem Pharmacol. 1984;33(21):3333-3338

53. Itoh $\mathrm{T}$, Ninomiya $\mathrm{M}$, Nozawa $\mathrm{Y}$, Koketsu M. Chalcone glycosides isolated from aerial parts of Brassica rapa L. 'hidabeni' suppress antigen-stimulated degranulation in rat basophilic leukemia RBL-2H3 cells. Bioorg Med Chem. 2010;18(19):7052-7057.

54. Tanifuji S, Aizu-Yokota E, Funakoshi-Tago M, Sonoda Y, Inoue H, Kasahara T. Licochalcones suppress degranulation by decreasing the intracellular $\mathrm{Ca}^{+}$level and tyrosine phosphorylation of ERK in RBL2H3 cells. Int Immunopharmacol. 2010;10(7):769-776.

55. Spits H, Artis D, Colonna M, et al. Innate lymphoid cells - a proposal for uniform nomenclature. Nat Rev Immunol. 2013;13(2):145-149.

56. Hepworth MR, Sonnenberg GF. Regulation of the adaptive immune system by innate lymphoid cells. Curr Opin Immunol. 2014;27 $75-82$.

57. Gao X, Deeb D, Liu Y, Gautam S, Dulchavsky SA, Gautam SC. Immunomodulatory activity of xanthohumol: inhibition of $\mathrm{T}$ cell proliferation, cell-mediated cytotoxicity and Th1 cytokine production through suppression of NF-kappaB. Immunopharmacol Immunotoxicol. 2009;31(3):477-484.

58. Harikumar KB, Kunnumakkara AB, Ahn KS, et al. Modification of the cysteine residues in IkappaBalpha kinase and NF-kappaB (p65) by xanthohumol leads to suppression of NF-kappaB-regulated gene products and potentiation of apoptosis in leukemia cells. Blood. 2009;113(9): 2003-2013.

59. Geissmann F, Manz MG, Jung S, Sieweke MH, Merad M, Lay K. Development of monocytes, macrophages, and dentritic cells. Science. 2010;327(5966):656-661.
60. Parihar A, Eubank TD, Doseff AI. Monocytes and macrophages regulate immunity through dynamic networks of survival and cell death. J Innate Immun. 2010;2(3):204-215.

61. Fraser IP, Koziel H, Ezekowitz RA. The serum mannose-binding protein and the macrophage mannose receptor are pattern recognition molecules that link innate and adaptive immunity. Semin Immunol. 1998;10(5): 363-372.

62. Savill J. Recognition and phagocytosis of cells undergoing apoptosis. Brit Med Bull. 1997;53(3):491-508.

63. Park PH, Kim HS, Jin XY, et al. KB-34, a newly synthesized chalcone derivative, inhibits lipopolysaccharide-stimulated nitric oxide production in RAW 264.7 macrophages via heme oxygenase- 1 induction and blockade of activator protein-1. Eur J Pharmacol. 2009;606(1-3):215-224.

64. Ban HS, Suzuki K, Lim SS, et al. Inhibition of lipopolysaccharideinduced expression of inducible nitric oxide synthase and tumor necrosis factor-alpha by 2'-hydroxychalcone derivatives in RAW 264.7 cells. Biochem Pharmacol. 2004;67(8):1549-1557.

65. Herencia F, Ferrándiz ML, Ubeda A, et al. 4-dimethylamino-3',4'dimethoxychalcone downregulates iNOS expression and exerts antiinflammatory effects. Free Radic Biol Med. 2001;30(1):43-50.

66. Roh E, Lee HS, Kwak JA, et al. MD-2 as the target of nonlipid chalcone in the inhibition of endotoxin LPS-induced TLR4 activity. $J$ Infect Dis. 2011;203(7):1012-1020.

67. Hirai S, Kim YI, Goto T, et al. Inhibitory effect of naringenin chalcone on inflammatory changes in the interaction between adipocytes and macrophages. Life Sci. 2007;81(16):1272-1279.

68. Tanaka H, Nakamura S, Onda K, Tazaki T, Hirano T. Sofalcone, an anti-ulcer chalcone derivative, suppresses inflammatory crosstalk between macrophages and adipocytes and adipocyte differentiation: implication of heme-oxygenase-1 induction. Biochem Biophys Res Commun. 2009;381(4):566-571.

69. Ko HH, Tsao LT, Yu KL, Liu CT, Wang JP, Lin CN. Structure-activity relationship studies on chalcone derivatives. the potent inhibition of chemical mediators release. Bioorg Med Chem. 2003;11(1):105-111.

70. Won SJ, Liu CT, Tsao LT, et al. Synthetic chalcones as potential antiinflammatory and cancer chemopreventive agents. Eur J Med Chem. 2005;40(1):103-112.

71. Hatziieremia S, Gray AI, Ferro VA, Paul A, Plevin R. The effects of cardamonin on lipopolysaccharide-induced inflammatory protein production and MAP kinase and NFkappaB signalling pathways in monocytes/macrophages. Br J Pharmacol. 2006;149(2):188-198.

72. Liew CY, Lam KW, Kim MK, et al. Effects of 3-(2-Hydroxyphenyl)1-(5-methyl-furan-2-y-1) propenone (HMP) upon signalling pathways of lipopolysaccharide-induced iNOS synthesis in RAW 264.7 cells. Int Immunopharmacol. 2011;11(1):85-95.

73. Jantan I, Bukhari SN, Adekoya OA, Sylte I. Studies of synthetic chalcone derivatives as potential inhibitors of secretory phospholipase A2, cyclooxygenases, lipoxygenase and pro-inflammatory cytokines. Drug Des Devel Ther. 2014;8:1405-1418.

74. Bandgar BP, Gawande SS. Synthesis and biological screening of a combinatorial library of beta-chlorovinyl chalcones as anticancer, anti-inflammatory and antimicrobial agents. Bioorg Med Chem. 2010; 18(5):2060-2065.

75. Kil JS, Son Y, Cheong YK, et al. Okanin, a chalcone found in the genus Bidens, and 3-penten-2-one inhibit inducible nitric oxide synthase expression via heme oxygenase-1 induction in RAW264.7 macrophages activated with lipopolysaccharide. J Clin Biochem Nutr. 2012;50(1):53-58.

76. Semple JW, Italiano JE, Freedman J. Platelets and the immune continuum. Nat Rev Immunol. 2011;11(4):264-274.

77. Li C, Li J, Li Y, et al. Crosstalk between platelets and the immune system: old systems with new discoveries. Adv Hematol. 2012;2012: 384685.

78. Lin CN, Lee TH, Hsu MF, Wang JP, Ko FN, Teng CM. 2',5'Dihydroxychalcone as a potent chemical mediator and cyclooxygenase inhibitor. J Pharm Pharmacol. 1997;49(5):530-536.

79. Ko HH, Hsieh HK, Liu CT, Lin HC, Teng CM, Lin CN. Structureactivity relationship studies on chalcone derivatives: potent inhibition of platelet aggregation. J Pharm Pharmacol. 2004;56(10):1333-1337. 
80. Reddy MVB, Tsai WJ, Qian K, Lee KH, Wu TS. Structure-activity relationships of chalcone analogs as potential inhibitors of ADPand collagen-induced platelet aggregation. Bioorgan Med Chem. 2011;19(24):7711-7719.

81. Schwartz A, Middleton E. Comparison of the effects of quercetin with those of other flavonoids on the generation and effector function of cytotoxic T lymphocytes. Immunopharmacology. 1984;7(2):115-126.

82. Namgoong SY, Son KH, Chang HW, Kang SS, Kim HP. Effects of naturally occurring flavonoids on mitogen-induced lymphocyte proliferation and mixed lymphocyte culture. Life Sci. 1994;54(5):313-320.

83. Choi JM, Kim HJ, Lee KY, Choi HJ, Lee IS, Kang BY. Increased IL-2 production in T cells by xanthohumol through enhanced NF-AT and AP-1 activity. Int Immunopharmacol. 2009;9(1):103-107.
84. Barfod L, Kemp K, Hansen M, Kharazmi A. Chalcones from Chinese liquorice inhibit proliferation of T cells and production of cytokines. Int Immunopharmacol. 2002;2(4):545-555.

85. Iwamura C, Shinoda K, Yoshimura M, Watanabe Y, Obata A, Nakayama T. Naringenin chalcone suppresses allergic asthma by inhibiting the type-2 function of CD4 T cells. Allergol Int. 2010;59(1):67-73.

86. Fang F, Tang Y, Gao Z, Xu Q. A novel regulatory mechanism of naringenin through inhibition of T lymphocyte function in contact hypersensitivity suppression. Biochem Biophys Res Commun. 2010;397(2):163-169.

\section{Publish your work in this journal}

Drug Design, Development and Therapy is an international, peerreviewed open-access journal that spans the spectrum of drug design and development through to clinical applications. Clinical outcomes, patient safety, and programs for the development and effective, safe, and sustained use of medicines are a feature of the journal, which has also been accepted for indexing on PubMed Central. The manuscript management system is completely online and includes a very quick and fair peer-review system, which is all easy to use. Visit http://www.dovepress.com/testimonials.php to read real quotes from published authors.

Submit your manuscript here: http://www.dovepress.com/drug-design-development-and-therapy-journal 